\title{
A Behavior Genetic Study of the Connection Between Social Values and Personality
}

\author{
Julie Aitken Schermer, ${ }^{1}$ Philip A. Vernon, ${ }^{1}$ Gregory R. Maio ${ }^{2}$ and Kerry L. Jang ${ }^{3}$ \\ ${ }^{1}$ The University of Western Ontario, Canada \\ ${ }^{2}$ Cardiff University, United Kingdom \\ ${ }^{3}$ University of British Columbia, Canada
}

\begin{abstract}
The present research examined the extent to which relations between social values and personality are due to shared genetic or environmental factors. Using the Rokeach (1973) Value Survey and a scoring key from Schwartz and Bilsky (1990), seven value scores (enjoyment, achievement, self-direction, maturity, prosocial, security, and restrictive conformity) were derived in a sample of twins. As expected, all of the value scales were found to have a significant genetic component, with values ranging from $36 \%$ for enjoyment to $63 \%$ for prosocial, and there were numerous significant phenotypic correlations found between the value scales and personality scores. Most important, bivariate genetic analyses revealed that some of these phenotypic correlations could be attributed to common genetic or environmental factors.
\end{abstract}

Keywords: values, genetics, twins

Often, when people defend their views on controversial issues, they end up citing particular values. For instance, people may justify war as a way to defend freedom, they may justify programs to confront racism (e.g., affirmative action) by referring to the importance of equality, and they may justify unemployment benefit programs by referring to the importance of helpfulness. In this way, values appear central to many opinions and actions. Moreover, to the extent that these opinions and behaviors show consistency over time and situations, values should be correlated with personality. Although there is abundant evidence fitting this view (as described below), there is a paucity of knowledge about the extent to which any connections between values and personality are due to common biological antecedents. The purpose of the present study was to address this issue.

\section{Values and Personality}

Previous research has demonstrated that values correlate with important personality dimensions (see, e.g., Furnham, 1984, or Rim, 1984). Olver and Mooradian (2003) state that personality is largely influenced by nature (genes), whereas values are learned characteristics that are shaped by nurture (the environment) and that the interaction between the two domains is still unclear. In their study, Olver and Mooradian (2003) correlated the
Big Five personality factors - neuroticism, extroversion, openness to experience, agreeableness, and conscientiousness - with the 10 values from Schwartz's cross-cultural model (Schwartz et al., 2001). The 10 values in Schwartz's model include power, achievement, hedonism, stimulation, self-direction, universalism, benevolence, tradition, conformity, and security, and these value types have been validated in extensive cross-cultural research across more than 70 nations (see Schwartz \& Rubel, 2005).

Olver and Mooradian (2003) found that openness to experience correlated positively with universalism, stimulation, and self-direction, while correlating negatively with conformity and tradition. Agreeableness was positively related to universalism, benevolence, tradition, and conformity, and negatively related to power, achievement, and stimulation. Conscientiousness was positively correlated with conformity and achievement and negatively correlated with stimulation. Extraversion had a positive

RECEIVED 27 January, 2011; ACCEPTED 01 March, 2011.

ADDRESS FOR CORRESPONDENCE: Julie Aitken Schermer, Management and Organizational Studies, Faculty of Social Science, The University of Western Ontario, London, Ontario, Canada N6A 5C2. E-mail: jharris@uwo.ca 
correlation with power and stimulation and a negative correlation with universalism. Neuroticism was not found to have robust correlations with the values, and two of the values, security and hedonism, were not found to correlate significantly with the personality dimensions.

Similar results have been reported by Roccas et al. (2002) and by Haslam et al. (2009). Roccas et al. (2002) conducted a further examination by assessing the correlations between the values and the facets of the Big Five factors. Certain facets of the factors were found to correlate significantly with the values even when the factor itself was not found to correlate significantly (e.g., the extraversion facet of warmth with the benevolence value scale). These results show that examination of the personality facets can reveal more information about values than examination of the personality factors alone.

\section{Behavior Genetic Studies}

Studies have revealed genetic components of values and personality separately. Some of the studies focused on values in specific social domains. For instance, Waller et al. (1990) examined the genetic and environmental influences on religious values, interests, and attitudes in twins reared together and reared apart. Results indicated that 52\% of the variability in religious values was attributed to a heritable component (see also review by Bouchard et al., 2004). In addition, Keller et al. (1992) examined the heritability of six values related to work (including achievement, comfort, status, altruism, safety, and autonomy) in twins reared apart. These researchers found that all had a genetic component, with heritabilities ranging from $18 \%$ for altruism to $56 \%$ for achievement. Common environment effects were also found for the achievement, status, comfort, and autonomy work value factors. Taken together, these studies suggest that religious and occupational values may have a genetic component.

More recently, Schermer et al. (2008) provided a broader analysis of the genetic and environmental components of values by using the Portrait Value Questionnaire (PVQ; Schwartz et al., 2001). The PVQ measures 10 value types in Schwartz's cross-cultural model with 40 items. Schermer et al. (2008) found that 9 of the 10 value scales showed a genetic effect, with heritability estimates ranging from $10.8 \%$ to $38 \%$ (the exception was the achievement value scale, which was best explained by environmental effects). All of the PVQ scales were found to have unique environmental effects, which were moderate to large.

With regard to personality, behavior genetic studies have typically found that approximately $50 \%$ of the observed variance in personality is due to additive genetic effects, $50 \%$ is due to unique environmental effects, and common environmental influences are small (see review by Johnson et al., in press). Vernon et al. (1997) reported the heritability values of the PRF for the present sample. Seventeen of the 20 scales were found to have a genetic component, with heritability estimates ranging from $26 \%$ for order to $65 \%$ for harm avoidance. Three of the scales (abasement, cognitive structure, and dominance) were found to be best fit by a common and unique environmental factor model, with common environmental estimates ranging from $27 \%$ for cognitive structure to $38 \%$ for dominance.

In sum, behavior genetic studies provide cogent evidence for a heritable aspect of values and personality. This evidence makes salient the possibility that the shared variance between values and personality is at least partly due to shared genetic components. Such a result would provide an important expansion of our understanding of the relationship between values and personality.

\section{The Present Research}

The present research examined the heritable aspect of the covariation between values and personality by examining relations between measures of values and personality in a sample of twins. The value scales were derived from The Rokeach Value Survey [RVS; (Rokeach, 1973)]. This measure asks participants to rank two sets of 18 value terms relating to desired end states (e.g., mature love, a sense of accomplishment) or ways of conduct (e.g., forgiving, selfcontrolled). Although this ranking system has been criticized by some (see Gibbins \& Walker, 1993), it has been one of the most widely used measures of values, and others have reported that the ranking system is best in situations where value choice is of interest (see Thompson et al., 1982). For our purposes, it is important that several of the 10 value types that were found in Schwartz's (1992) extensive cross-cultural research can be measured with the RVS, using a method developed and validated by Schwartz and Bilsky (1987; 1990). This method enables us to extract wellvalidated value scores. To probe both personality factors and facets, the study utilized the 20 personality scales from the Personality Research Form (PRF; Jackson, 1986).

\section{Method}

\section{Participants}

Participants were 258 adult sibling pairs with an average age of 23.87 years $(S D=6.23$, range 13 to 45 ) from the Western Ontario Twin Project, who were recruited through newspaper advertisements. The sample consisted of 148 monozygotic (MZ) female twins, $38 \mathrm{MZ}$ male twins, 82 dizygotic (DZ) female twins, 18 DZ male twins, 30 DZ opposite sex twins, 104 non-twin sisters, 32 brothers, and 64 opposite sex non-twin siblings. For the phenotypic analyses, all participants were included and were treated as individuals. For analyses involving heritability and environmental estimates, MZ and same-sex DZ twins only were included in the analyses.

\section{Test Session and Materials}

Each participant completed the self-report RVS (Rokeach, 1973), in which participants rank two sets of 18 values (36 
in total) in terms of importance (from most to least). As stated in the introduction, one set of values represents terminal or end state values and the other set represents instrumental or 'ways of being' values. Participants also completed the PRF (Jackson, 1986), which is a 353-item personality scale for assessing 20 personality traits. Participants responded to each item using a true-false response key. Both of these measures were part of a larger battery of questionnaires (see Vernon et al., 1997).

\section{Results}

\section{Creation of Value Scales}

As stated above, the scoring key set out by Schwartz and Bilsky (1990) was used to construct the seven value scales. As might be expected, the internal consistency coefficient alpha values were low to moderate (ranging from .17 for the 2 -item security scale to .52 for the 8 -item prosocial scale). These lower alpha values may be expected because of the nature of the ipsative response key (ranking) for the items, resulting in lower inter-item correlations.

\section{Genetic Analyses of Value Scales}

Within twin pair correlations were computed for the seven value scales (see Table 1) demonstrate that there was greater similarity in scale scores for the MZ twins compared to the DZ twins. Univariate genetic analyses were conducted on the within twin pair variance-covariance matrices using the program Mx (Neale et al., 2006). In these analyses, the phenotypic score is expressed as a linear function of three factors: genetic (A), common environment (C), and specific environment (E) (Neale \& Cardon, 1992). Heritability $\left(\mathrm{a}^{2}\right)$, common environment $\left(\mathrm{c}^{2}\right)$, and specific environment $\left(\mathrm{e}^{2}\right)$ values are computed from the standardized parameter estimates. These weights are standardized such that the total phenotypic variance is one (or $100 \%)$. In conducting these analyses, a full ACE model is first tested, followed by three reduced models (AE, CE, and E-only). The model with the lowest chi-square per degree of freedom, the lowest Akaike's Information Criterion (AIC) value, and which is the most parsimonous, is considered to be the best fitting model. The results of the univariate genetic analyses are listed in Table 1 .

TABLE 1

Univariate Genetic Analyses of the Value Scales

\begin{tabular}{lcccc}
\hline Value Factor & $\mathrm{MZr}$ & $\mathrm{DZr}$ & $\mathrm{a}^{2}$ & $\mathrm{e}^{2}$ \\
\hline Enjoyment & $.37^{\star}$ & .22 & $.36(.19$ to .51$)$ & .64 (.49 to .81$)$ \\
Achievement & $.45^{\star}$ & .19 & $.43(.26$ to .57$)$ & .57 (.43 to .74$)$ \\
Self-direction & $.53^{\star}$ & $.32^{\star}$ & $.53(.37$ to .65$)$ & $.47(.35$ to .63$)$ \\
Maturity & $.44^{\star}$ & .09 & $.42(.24$ to .56$)$ & .58 (.44 to .76$)$ \\
Prosocial & $.68^{\star}$ & .06 & $.63(.49$ to .73$)$ & .37 (.27 to .51$)$ \\
Security & $.47^{\star}$ & .18 & $.46(.29$ to .60$)$ & $.54(.40$ to .71$)$ \\
Restrictive Conformity & $.43^{\star}$ & .20 & $.42(.25$ to .57$)$ & .58 (.43 to .75$)$ \\
\hline
\end{tabular}

Note: * $p<.01$ (two-tailed); all value scales were best fit by an AE model.
Mean value scale scores were assessed across the four zygosity groups (MZ female, MZ male, DZ female, and DZ male) using one-way ANOVAs. No significant differences were found for the seven scales, with $F$ values ranging from .05 $(p>.90)$ to $1.8(p>.15)$. Following univariate genetic analyses, all seven of the value scales were found to be best fit by the AE model and have a significant genetic component in which the $95 \%$ confidence interval for the heritability estimate did not include zero. Heritability values ranged from $36 \%$ for the enjoyment scale to $63 \%$ for the prosocial scale with the remaining variance due to unique environmental effects. Although common environment (C) effects were nonsignificant, this does not mean that the effects are not present (i.e., should not be considered to be a value of zero).

\section{Bivariate Genetic Analyses of Value and Personality Scales}

Inspection of Table 2 reveals that, despite the lower reliability of the value scales, the phenotypic correlations (rp) between the value and personality scales were often significant and in the expected directions. For instance, the achievement value correlated positively with the PRF scales of achievement, affiliation, change, dominance, endurance, exhibition, and social recognition, while being negatively correlated with abasement and nurturance. In addition, security values correlated positively with cognitive structure, harm avoidance, nurturance, and succorance, and negatively with autonomy and change. Bivariate genetic analyses were performed to further examine the covariance between each of the values and personality scales. Cholesky or triangular decomposition (see Neale \& Cardon, 1992) was applied to the MZ and DZ mean square between- and within-pair covariance matrices to calculate genetic and environmental correlations. For these analyses, a twin's score on a value scale is correlated with their co-twin's score on a personality scale. If these cross-correlations are higher for MZ twins than for DZ twins, this suggests that the phenotypic correlation between the value score and the personality score is due to some common genetic factor(s).

In conducting the multivariate genetic analyses, four models were computed and the fit estimates were then assessed (Neale \& Cardon, 1992). In particular, a full ACE model, an AE model, a CE model, as well as an environmental (E) covariation-only model was computed for each pair of variables. Model fit and the selection of the bestfitting model is determined the same way as was described above for the univariate genetic models. For each of the multivariate genetic models computed in the present analyses, the AE or CE model was found to fit better than the ACE and E-only models.

Table 2 lists the results of the multivariate genetic analyses. One cautionary note in reading the genetic and environmental correlations is that the confidence intervals should be considered. Given the relatively small 
TABLE 2

Phenotypic (rp), Genetic (rg), Common Environmental (rc), and Unique Environmental (re) Correlations Between the Value Scales and the PRF Scales

\begin{tabular}{|c|c|c|c|c|c|c|c|}
\hline PRF Scale & Enjoyment & Achievement & Self-direction & Maturity & Prosocial & Security & Restrictive conformity \\
\hline Abasement & $\begin{array}{c}r p=-.02 \\
r g=- \\
r c=-.01 \\
(-.42 \text { to } .40) \\
r e=.04 \\
(-.13 \text { to } .20)\end{array}$ & $\begin{array}{c}r p=-.18 * \star \\
r g=-.25 \\
(-.58 \text { to } .11) \\
r c=- \\
r e=-.12 \\
(-.30 \text { to } .07)\end{array}$ & $\begin{array}{c}r p=-.16^{\star \star} \\
r g=-.29 \\
(-.62 \text { to } .03) \\
r c=- \\
r e=-.15 \\
(-.33 \text { to } .05)\end{array}$ & $\begin{array}{c}r p=-.05 \\
r g=.02 \\
(-.36 \text { to } .40) \\
r c=- \\
r e=-.04 \\
(-.23 \text { to } .16)\end{array}$ & $\begin{array}{c}r p=.28^{\star \star} \\
r g=.30 \\
(-.01 \text { to } .59) \\
r c=- \\
r e=.16 \\
(-.03 \text { to } .35)\end{array}$ & $\begin{array}{c}r p=-.01 \\
r g=-.07 \\
(-.45 \text { to } .26) \\
r c=- \\
r e=.17 \\
(-.03 \text { to } .35)\end{array}$ & $\begin{array}{c}r p=.05 \\
r g=.15 \\
(-.21 \text { to } .53) \\
r c=- \\
r e=.01 \\
(-.18 \text { to } .20)\end{array}$ \\
\hline Achievement & $\begin{array}{c}\mathrm{rp}=-.16^{\star \star} \\
\mathrm{rg}=-.29 \\
(-.60 \text { to } .05) \\
\mathrm{rc}=- \\
\mathrm{re}=-.16 \\
(-.34 \text { to } .03)\end{array}$ & $\begin{array}{c}\mathrm{rp}=.31^{\star \star} \\
\mathrm{rg}=.54 \\
(.26 \text { to } .81) \\
\mathrm{rc}=- \\
\mathrm{re}=.07 \\
(-.13 \text { to } .26)\end{array}$ & $\begin{array}{c}r p=.11 \\
r g=.35 \\
(.08 \text { to } .62) \\
r c=- \\
r e=-.15 \\
(-.34 \text { to } .05)\end{array}$ & $\begin{array}{c}r p=.04 \\
r g=.01 \\
(-.32 \text { to } .32) \\
r c=- \\
r e=.13 \\
(-.07 \text { to } .32)\end{array}$ & $\begin{array}{c}r p=-.21^{\star \star} \\
r g=-.28 \\
(-.01 \text { to }-.53) \\
r c=- \\
r e=.02 \\
(0.18 \text { to } .22)\end{array}$ & $\begin{array}{c}r p=.00 \\
r g=-.11 \\
(-.42 \text { to } .18) \\
r c=- \\
r e=.12 \\
(-.07 \text { to } .31)\end{array}$ & $\begin{array}{c}r p=-.05 \\
r g=-.22 \\
(-.52 \text { to } .09) \\
r c=- \\
r e=-.02 \\
(-.21 \text { to } .18)\end{array}$ \\
\hline Affiliation & $\begin{array}{c}r p=.13^{*} \\
r g=-.05 \\
(-.40 \text { to } .28) \\
r c=- \\
r e=.13 \\
\text { (-.06 to } .31)\end{array}$ & $\begin{array}{c}r p=.16^{*} \\
r g=.03 \\
(-.28 \text { to } .33) \\
r c=- \\
r e=.06 \\
(-.13 \text { to } .25)\end{array}$ & $\begin{array}{c}r p=-.15^{\star} \\
r g=-.19 \\
(-.45 \text { to } .08) \\
r c=- \\
r e=-.06 \\
(-.25 \text { to } .14)\end{array}$ & $\begin{array}{c}r p=-.19 * * \\
r g=-.23 \\
(-.52 \text { to } .09) \\
r c=- \\
r e=-.11 \\
(-.29 \text { to } .08)\end{array}$ & $\begin{array}{c}r p=.15^{\star} \\
r g=.29 \\
(.04 \text { to } .54) \\
r c=- \\
r e=.06 \\
(-.14 \text { to } .26)\end{array}$ & $\begin{array}{c}r p=.05 \\
r g=.15 \\
(-.15 \text { to } .45) \\
r c=- \\
r e=-.05 \\
(-.24 \text { to } .14)\end{array}$ & $\begin{array}{c}r p=-.14^{*} \\
r g=-.09 \\
(-.39 \text { to } .22) \\
r c=- \\
r e=-.09 \\
(-.28 \text { to } .10)\end{array}$ \\
\hline Aggression & $\begin{array}{c}r p=.05 \\
r g=.11 \\
(-.33 \text { to } .51) \\
r c=- \\
r e=.10 \\
(-.09 \text { to } .28)\end{array}$ & $\begin{array}{c}r p=.12 \\
r g=.32 \\
(-.04 \text { to } .70) \\
r c=- \\
r e=.03 \\
(-.16 \text { to } .22)\end{array}$ & $\begin{array}{c}r p=.10 \\
r g=.33 \\
(.01 \text { to } .71) \\
r c=- \\
r e=-.10 \\
(-.29 \text { to } .09)\end{array}$ & $\begin{array}{c}r p=-.01 \\
r g=-.24 \\
(-.67 \text { to } .14) \\
r c=- \\
r e=.06 \\
(-.13 \text { to } .25)\end{array}$ & $\begin{array}{c}r p=-.18^{\star \star} \\
r g=-.29 \\
(-.58 \text { to } .03) \\
r c=- \\
r e=-.19 \\
(-.37 \text { to } .01)\end{array}$ & $\begin{array}{c}r p=.02 \\
r g=-.04 \\
(-.40 \text { to } .32) \\
r c=- \\
r e=.03 \\
\text { (-.16 to } .22)\end{array}$ & $\begin{array}{c}r p=.00 \\
r g=-.02 \\
(-.43 \text { to } .33) \\
r c=- \\
r e=.14 \\
(-.05 \text { to } .33)\end{array}$ \\
\hline Autonomy & $\begin{array}{c}\mathrm{rp}=-.19^{\star *} \\
\mathrm{rg}=-.09 \\
(-.39 \text { to } .24) \\
\mathrm{rc}=- \\
\mathrm{re}=-.16 \\
(-.34 \text { to } .03)\end{array}$ & $\begin{array}{c}r p=.08 \\
r g=.22 \\
(-.06 \text { to } .49) \\
r c=- \\
r e=.07 \\
(-.13 \text { to } .26)\end{array}$ & $\begin{array}{c}r p=.46^{\star *} \\
r g=.69 \\
(.48 \text { to } .89) \\
r c=- \\
r e=.03 \\
(-.16 \text { to } .23)\end{array}$ & $\begin{array}{c}\mathrm{rp}=.29^{\star *} \\
\mathrm{rg}=.51 \\
(.23 \text { to } .77) \\
\mathrm{rc}=- \\
\mathrm{re}=.12 \\
(-.08 \text { to } .31)\end{array}$ & $\begin{array}{c}r p=-.25^{\star \star} \\
r g=-.44 \\
(-.20 \text { to }-.67) \\
r c=- \\
r e=.03 \\
(-.18 \text { to } .23)\end{array}$ & $\begin{array}{c}r p=-.27^{\star \star} \\
r g=-.46 \\
(-.19 \text { to }-.73) \\
r c=- \\
r e=-.02 \\
(-.21 \text { to } .18)\end{array}$ & $\begin{array}{c}r p=-.24^{\star \star} \\
r g=-.56 \\
(-.29 \text { to }-.80) \\
r c=- \\
r e=-.11 \\
(-.30 \text { to } .09)\end{array}$ \\
\hline Change & $\begin{array}{c}r p=-.04 \\
r g=-.18 \\
(-.52 \text { to } .13) \\
r c=- \\
r e=.07 \\
(-.12 \text { to } .26)\end{array}$ & $\begin{array}{c}r p=.18^{\star \star} \\
r g=.18 \\
(-.10 \text { to } .44) \\
r c=- \\
r e=.19 \\
(-.01 \text { to } .37)\end{array}$ & $\begin{array}{c}r p=.30^{\star \star} \\
r g=.47 \\
(.23 \text { to } .69) \\
r c=- \\
r e=.06 \\
(-.14 \text { to } .25)\end{array}$ & $\begin{array}{c}r p=.08 \\
r g=.40 \\
(.12 \text { to } .70) \\
r c=- \\
r e=-.10 \\
(-.29 \text { to } .10)\end{array}$ & $\begin{array}{c}r p=-.13^{\star} \\
r g=-.14 \\
(-.37 \text { to } .10) \\
r c=- \\
r e=-.20 \\
(-.38 \text { to } .01)\end{array}$ & $\begin{array}{c}\mathrm{rp}=-.21^{\star \star} \\
\mathrm{rg}=-.32 \\
(-.04 \text { to }-.58) \\
\mathrm{rc}=- \\
\mathrm{re}=-.06 \\
(-.26 \text { to } .14)\end{array}$ & $\begin{array}{c}r p=-.26^{\star *} \\
r g=-.66 \\
(-.39 \text { to }-.96) \\
r c=- \\
r e=.07 \\
(-.13 \text { to } .26)\end{array}$ \\
\hline Cognitive structure & $\begin{array}{c}r p=-.01 \\
r g=.17 \\
(-.29 \text { to } .73) \\
r c=- \\
r e=.02 \\
(-.17 \text { to } .21)\end{array}$ & $\begin{array}{c}r p=.08 \\
r g=.25 \\
(-.16 \text { to } .72) \\
r c=- \\
r e=-.04 \\
(-.23 \text { to } .15)\end{array}$ & $\begin{array}{c}r p=-.02 \\
r g=-.32 \\
(-.74 \text { to } .05) \\
r c=- \\
r e=-.03 \\
(-.22 \text { to } .17)\end{array}$ & $\begin{array}{c}r p=-.13^{\star} \\
r g=-.31 \\
(-.73 \text { to } .13) \\
r c=- \\
r e=-.18 \\
(-.36 \text { to } .02)\end{array}$ & $\begin{array}{c}r p=-.16^{\star \star} \\
r g=-.35 \\
(-.01 \text { to }-.82) \\
r c=- \\
r e=.07 \\
(-.13 \text { to } .27)\end{array}$ & $\begin{array}{c}r p=.20^{\star \star} \\
r g=.60 \\
(.26 \text { to } .99) \\
r c=- \\
r e=.07 \\
(-.12 \text { to } .26)\end{array}$ & $\begin{array}{c}\mathrm{rp}=.23^{\star \star} \\
\mathrm{rg}=.66 \\
(.27 \text { to } 1.00) \\
\mathrm{rc}=- \\
\mathrm{re}=.13 \\
(-.06 \text { to } .32)\end{array}$ \\
\hline Defensiveness & $\begin{array}{c}r p=.03 \\
r g=.28 \\
(-.12 \text { to } .73) \\
r c=- \\
r e=-.05 \\
(-.24 \text { to } .14)\end{array}$ & $\begin{array}{c}r p=.09 \\
r g=.22 \\
(-.13 \text { to } .60) \\
r c=- \\
r e=-.07 \\
(-.26 \text { to } .12)\end{array}$ & $\begin{array}{c}r p=.07 \\
r g=-.09 \\
(-.44 \text { to } .22) \\
r c=- \\
r e=.24 \\
(.04 \text { to } .41)\end{array}$ & $\begin{array}{c}r p=-.07 \\
r g=-.53 \\
(-.15 \text { to }-1.00) \\
r c=- \\
r e=.14 \\
(-.05 \text { to } .33)\end{array}$ & $\begin{array}{c}r p=-.14^{*} \\
r g=-.06 \\
(-.35 \text { to } .27) \\
r c=- \\
r e=-.26 \\
(-.06 \text { to }-.44)\end{array}$ & $\begin{array}{c}r p=.07 \\
r g=.12 \\
(-.25 \text { to } .46) \\
r c=- \\
r e=.01 \\
(-.18 \text { to } .21)\end{array}$ & $\begin{array}{c}r p=.05 \\
r g=.19 \\
(-.19 \text { to } .54) \\
r c=- \\
r e=.09 \\
(-.10 \text { to } .28)\end{array}$ \\
\hline Dominance & $\begin{array}{c}r p=-.04 \\
r g=- \\
r c=-.09 \\
(-.47 \text { to } .28) \\
r e=.01 \\
(-.16 \text { to } .17)\end{array}$ & $\begin{array}{c}r p=.24^{\star \star} \\
r g=- \\
r c=.41 \\
(.08 \text { to } .72) \\
r e=.07 \\
(-.10 \text { to } .23)\end{array}$ & $\begin{array}{c}\mathrm{rp}=.22^{\star \star} \\
\mathrm{rg}=.44 \\
(.16 \text { to } .72) \\
\mathrm{rc}=- \\
\mathrm{re}=-.02 \\
(-.21 \text { to } .17)\end{array}$ & $\begin{array}{c}r p=.02 \\
r g=.03 \\
(-.32 \text { to } .37) \\
r c=- \\
r e=.02 \\
(-.17 \text { to } .21)\end{array}$ & $\begin{array}{c}r p=-.21^{\star \star} \\
r g=-.18 \\
(-.45 \text { to } .10) \\
r c=- \\
r e=-.03 \\
(-.23 \text { to } .16)\end{array}$ & $\begin{array}{c}r p=-.05 \\
r g=-.10 \\
(-.42 \text { to } .22) \\
r c=- \\
r e=.02 \\
(-.17 \text { to } .21)\end{array}$ & $\begin{array}{c}r p=-.16^{\star \star} \\
r g=- \\
r c=-.51 \\
(-.18 \text { to }-.82) \\
r e=-.11 \\
(-.27 \text { to } .06)\end{array}$ \\
\hline Endurance & $\begin{array}{c}r p=-.06 \\
r g=-.23 \\
(-.59 \text { to } .14) \\
r c=- \\
r e=-.04 \\
(-.22 \text { to } .15)\end{array}$ & $\begin{array}{c}r p=.18^{\star \star} \\
\text { rg }=.37 \\
(.04 \text { to } .72) \\
r c=- \\
r e=-.02 \\
(-.21 \text { to } .17)\end{array}$ & $\begin{array}{c}r p=.05 \\
r g=.13 \\
(-.16 \text { to } .45) \\
r c=- \\
r e=-.08 \\
(-.27 \text { to } .11)\end{array}$ & $\begin{array}{c}r p=.02 \\
r g=.14 \\
(-.20 \text { to } .50) \\
r c=- \\
r e=-.02 \\
(-.22 \text { to } .17)\end{array}$ & $\begin{array}{c}r p=-.11 \\
r g=-.27 \\
(-.59 \text { to } .02) \\
r c=- \\
r e=.17 \\
(-.03 \text { to } .35)\end{array}$ & $\begin{array}{c}r p=-.05 \\
r g=.06 \\
(-.26 \text { to } .39) \\
r c=- \\
r e=-.01 \\
(-.20 \text { to } .18)\end{array}$ & $\begin{array}{c}r p=-.02 \\
r g=-.07 \\
(-.42 \text { to } .27) \\
r c=- \\
r e=-.04 \\
(-.23 \text { to } .15)\end{array}$ \\
\hline Exhibition & $\begin{array}{c}r p=-.02 \\
r g=-.22 \\
(-.61 \text { to } .11) \\
r c=- \\
r e=.16 \\
(-.04 \text { to } .34)\end{array}$ & $\begin{array}{c}r p=.18^{\star \star} \\
r g=.14 \\
(-.16 \text { to } .42) \\
r c=- \\
r e=.16 \\
\text { (-.03 to } .35)\end{array}$ & $\begin{array}{c}r p=.12 \\
r g=.21 \\
(-.07 \text { to } .49) \\
r c=- \\
r e=-.08 \\
(-.27 \text { to } .12)\end{array}$ & $\begin{array}{c}r p=.05 \\
r g=.16 \\
(-.16 \text { to } .51) \\
r c=- \\
r e=-.07 \\
(-.27 \text { to } .13)\end{array}$ & $\begin{array}{c}r p=-.07 \\
r g=.06 \\
(-.19 \text { to } .32) \\
r c=- \\
r e=-.10 \\
(-.30 \text { to } .10)\end{array}$ & $\begin{array}{c}r p=-.10 \\
r g=-.11 \\
(-.41 \text { to } .19) \\
r c=- \\
r e=-.01 \\
(-.21 \text { to } .19)\end{array}$ & $\begin{array}{c}r p=-.21^{\star *} \\
r g=-.46 \\
(-.15 \text { to }-.78) \\
r c=- \\
r e=-.06 \\
(-.26 \text { to } .14)\end{array}$ \\
\hline
\end{tabular}


TABLE 2 (CONTINUED)

Phenotypic (rp), Genetic (rg), Common Environmental (rc), and Unique Environmental (re) Correlations Between the Value Scales and the PRF Scales

\begin{tabular}{|c|c|c|c|c|c|c|c|}
\hline PRF Scale & Enjoyment & Achievement & Self-direction & Maturity & Prosocial & Security & Restrictive conformity \\
\hline Harm avoidance & $\begin{array}{c}r p=.04 \\
r g=.04 \\
(-.24 \text { to } .32) \\
r c=- \\
r e=-.02 \\
(-.21 \text { to } .17)\end{array}$ & $\begin{array}{c}r p=-.08 \\
r g=-.06 \\
(-.30 \text { to } .19) \\
r c=- \\
r e=-.19 \\
(-.37 \text { to } .01)\end{array}$ & $\begin{array}{c}r p=-.26^{\star \star} \\
r g=-.29 \\
(-.08 \text { to }-.48) \\
r c=- \\
r e=-.09 \\
(-.28 \text { to } .11)\end{array}$ & $\begin{array}{c}r p=-.09 \\
r g=-.16 \\
(-.40 \text { to } .11) \\
r c=- \\
r e=-.12 \\
(-.31 \text { to } .08)\end{array}$ & $\begin{array}{c}r p=.10 \\
r g=.12 \\
(-.10 \text { to } .32) \\
r c=- \\
r e=.11 \\
(-.09 \text { to } .30)\end{array}$ & $\begin{array}{c}\mathrm{rp}=.24^{\star \star} \\
\mathrm{rg}=.35 \\
(.11 \text { to } .57) \\
\mathrm{rc}=-\frac{}{2} \\
\mathrm{re}=.20 \\
(.01 \text { to } .38)\end{array}$ & $\begin{array}{c}\mathrm{rp}=.17^{\star \star} \\
\mathrm{rg}=.24 \\
(-.01 \text { to } .48) \\
\mathrm{rc}=- \\
\mathrm{re}=.16 \\
(-.04 \text { to } .35)\end{array}$ \\
\hline Impulsivity & $\begin{array}{c}r p=.02 \\
r g=-.04 \\
(-.44 \text { to } .31) \\
r c=- \\
r e=.10 \\
(-.10 \text { to } .29)\end{array}$ & $\begin{array}{c}r p=-.02 \\
r g=-.21 \\
(-.55 \text { to } .11) \\
r c=- \\
r e=.23 \\
(.03 \text { to } .41)\end{array}$ & $\begin{array}{c}r p=-.07 \\
r g=.19 \\
(-.11 \text { to } .50) \\
r c=- \\
r e=-.02 \\
(-.23 \text { to } .18)\end{array}$ & $\begin{array}{c}r p=.05 \\
r g=.16 \\
(-.18 \text { to } .51) \\
r c=- \\
r e=.02 \\
(-.18 \text { to } .22)\end{array}$ & $\begin{array}{c}r p=.11 \\
r g=.15 \\
(-.12 \text { to } .44) \\
r c=- \\
r e=-.20 \\
(-.39 \text { to } .02)\end{array}$ & $\begin{array}{c}r p=-.10 \\
r g=-.43 \\
(-.13 \text { to }-.73) \\
r c=- \\
r e=.03 \\
(-.17 \text { to } .23)\end{array}$ & $\begin{array}{c}r p=-.10 \\
r g=-.17 \\
(-.52 \text { to } .18) \\
r c=- \\
r e=-.14 \\
(-.34 \text { to } .07)\end{array}$ \\
\hline Nurturance & $\begin{array}{c}r p=-.02 \\
r g=- \\
r c=-.02 \\
(-.36 \text { to } .33) \\
r e=-.05 \\
(-.21 \text { to } .12)\end{array}$ & $\begin{array}{c}r p=-.15^{\star} \\
r g=- \\
r c=-.09 \\
(-.38 \text { to } .24) \\
r e=-.25 \\
(-.09 \text { to }-.40)\end{array}$ & $\begin{array}{c}\mathrm{rp}=-.23^{\star \star} \\
\mathrm{rg}=-.51 \\
(-.25 \text { to }-.76) \\
\mathrm{rc}=- \\
\mathrm{re}=-.01 \\
(-.19 \text { to } .18)\end{array}$ & $\begin{array}{c}r p=-.10 \\
r g=-.08 \\
(-.39 \text { to } .24) \\
r c=- \\
r e=-.10 \\
(-.28 \text { to } .09)\end{array}$ & $\begin{array}{c}r p=.42^{\star \star} \\
r g=.47 \\
(.23 \text { to } .67) \\
r c=- \\
r e=.31 \\
\text { (.12 to } .47)\end{array}$ & $\begin{array}{c}r p=.16^{\star} \\
r g=.27 \\
(-.02 \text { to } .55) \\
r c=- \\
\text { re }=.04 \\
\text { (-.15 to } .22)\end{array}$ & $\begin{array}{c}r p=-.15^{\star} \\
r g=-.07 \\
(-.38 \text { to } .24) \\
r c=- \\
r e=-.04 \\
(-.23 \text { to } .15)\end{array}$ \\
\hline Order & $\begin{array}{c}r p=.10 \\
r g=-.03 \\
(-.48 \text { to } .41) \\
r c=- \\
r e=.06 \\
(-.13 \text { to } .24)\end{array}$ & $\begin{array}{c}r p=-.01 \\
r g=.22 \\
(-.16 \text { to } .63) \\
r c=- \\
r e=-.08 \\
(-.26 \text { to } .11)\end{array}$ & $\begin{array}{c}r p=-.09 \\
r g=- \\
r c=-.42 \\
(-.05 \text { to }-.90) \\
r e=.10 \\
(-.07 \text { to } .26)\end{array}$ & $\begin{array}{c}r p=-.14^{\star} \\
r g=-.25 \\
(-.63 \text { to } .18) \\
r c=- \\
r e=-.14 \\
(-.32 \text { to } .05)\end{array}$ & $\begin{array}{c}r p=-.11 \\
r g=-.28 \\
(-.65 \text { to } .05) \\
r c=- \\
r e=.01 \\
(-.19 \text { to } .20)\end{array}$ & $\begin{array}{c}r p=.10 \\
r g=.68 \\
(.32 \text { to } 1.00) \\
r c=- \\
r e=-.11 \\
(-.29 \text { to } .08)\end{array}$ & $\begin{array}{c}r p=.28 * \star \\
r g=.60 \\
(.24 \text { to } .98) \\
r c=- \\
r e=.14 \\
(-.04 \text { to } .32)\end{array}$ \\
\hline Play & $\begin{array}{c}r p=.10 \\
r g=.43 \\
(.13 \text { to } .74) \\
r c=- \\
r e=-.04 \\
(-.23 \text { to } .15)\end{array}$ & $\begin{array}{c}r p=.06 \\
r g=-.09 \\
(-.40 \text { to } .20) \\
r c=- \\
r e=.07 \\
(-.12 \text { to } .26)\end{array}$ & $\begin{array}{c}r p=.02 \\
r g=-.05 \\
(-.32 \text { to } .22) \\
r c=- \\
r e=-.04 \\
(-.24 \text { to } .15)\end{array}$ & $\begin{array}{c}r p=-.03 \\
r g=-.28 \\
(-.60 \text { to } .02) \\
r c=- \\
r e=.12 \\
(-.08 \text { to } .30)\end{array}$ & $\begin{array}{c}r p=.04 \\
r g=.18 \\
(-.08 \text { to } .44) \\
r c=- \\
r e=-.05 \\
(-.25 \text { to } .15)\end{array}$ & $\begin{array}{c}r p=-.06 \\
r g=-.19 \\
(-.49 \text { to } .09) \\
r c=- \\
r e=.09 \\
(-.11 \text { to } .28)\end{array}$ & $\begin{array}{c}r p=-.17^{*} \\
r g=-.18 \\
(-.49 \text { to } .13) \\
r c=- \\
r e=-.04 \\
(-.24 \text { to } .15)\end{array}$ \\
\hline Sentience & $\begin{array}{c}r p=-.15^{\star} \\
r g=-.08 \\
(-.37 \text { to } .24) \\
r c=- \\
r e=-.17 \\
(-.36 \text { to } .02)\end{array}$ & $\begin{array}{c}r p=-.10 \\
r g=-.15 \\
(-.42 \text { to } .13) \\
r c=- \\
r e=.02 \\
(-.17 \text { to } .22)\end{array}$ & $\begin{array}{c}\mathrm{rp}=.18^{\star \star} \\
\mathrm{rg}=.07 \\
(-.19 \text { to } .32) \\
\mathrm{rc}=- \\
\mathrm{re}=.21 \\
(.01 \text { to } .39)\end{array}$ & $\begin{array}{c}r p=.27^{\star \star} \\
r g=.39 \\
(.10 \text { to } .65) \\
r c=- \\
r e=.09 \\
(-.11 \text { to } .28)\end{array}$ & $\begin{array}{c}r p=.02 \\
r g=.06 \\
(-.18 \text { to } .30) \\
r c=- \\
r e=-.11 \\
(-.31 \text { to } .09)\end{array}$ & $\begin{array}{c}r p=-.12 \\
r g=-.08 \\
(-.37 \text { to } .19) \\
r c=- \\
r e=.14 \\
(-.06 \text { to } .32)\end{array}$ & $\begin{array}{c}r p=-.24^{\star \star} \\
r g=-.41 \\
(-.12 \text { to }-.69) \\
r c=- \\
r e=-.08 \\
(-.27 \text { to } .12)\end{array}$ \\
\hline Social recognition & $\begin{array}{c}r p=.08 \\
r g=.04 \\
(-.27 \text { to } .34) \\
r c=- \\
r e=.18 \\
(-.01 \text { to } .36)\end{array}$ & $\begin{array}{c}r p=.12^{\star} \\
r g=.19 \\
(-.09 \text { to } .46) \\
r c=- \\
r e=.02 \\
\text { (-. } 17 \text { to } .22)\end{array}$ & $\begin{array}{c}r p=-.06 \\
r g=-.09 \\
(-.35 \text { to } .16) \\
r c=- \\
r e=.11 \\
(-.08 \text { to } .30)\end{array}$ & $\begin{array}{c}r p=-.22^{\star} \\
r g=-.71 \\
(-.45 \text { to }-1.00) \\
r c=- \\
r e=.07 \\
(-.12 \text { to } .26)\end{array}$ & $\begin{array}{c}r p=-.01 \\
r g=.10 \\
(-.14 \text { to } .34) \\
r c=- \\
r e=-.21 \\
(-.01 \text { to }-.39)\end{array}$ & $\begin{array}{c}r p=-.01 \\
r g=.20 \\
(-.07 \text { to } .46) \\
r c=- \\
r e=-.09 \\
(-.28 \text { to } .11)\end{array}$ & $\begin{array}{c}r p=.16^{*} \\
r g=.42 \\
(.15 \text { to } .69) \\
r c=- \\
r e=-.09 \\
(-.27 \text { to } .11)\end{array}$ \\
\hline Succorance & $\begin{array}{c}r p=.07 \\
r g=.12 \\
(-.24 \text { to } .44) \\
r c=- \\
r e=.16 \\
(-.03 \text { to } .34)\end{array}$ & $\begin{array}{c}r p=-.11 \\
r g=-.24 \\
(-.54 \text { to } .08) \\
r c=- \\
r e=-.05 \\
(-.24 \text { to } .15)\end{array}$ & $\begin{array}{c}r p=-.29 * \star \\
r g=-.65 \\
(-.40 \text { to }-.91) \\
r c=- \\
r e=.03 \\
(-.17 \text { to } .22)\end{array}$ & $\begin{array}{c}\mathrm{rp}=-.20^{\star *} \\
\mathrm{rg}=-.47 \\
(-.16 \text { to }-.79) \\
\mathrm{rc}=- \\
\mathrm{re}=-.06 \\
(-.25 \text { to } .14)\end{array}$ & $\begin{array}{c}\mathrm{rp}=.29^{\star \star} \\
\mathrm{rg}=.45 \\
(.19 \text { to } .70) \\
\mathrm{rc}=- \\
\mathrm{re}=-.01 \\
(-.21 \text { to } .19)\end{array}$ & $\begin{array}{c}r p=.22^{\star \star} \\
r g=.35 \\
(.04 \text { to } .67) \\
r c=- \\
r e=.05 \\
(-.15 \text { to } .24)\end{array}$ & $\begin{array}{c}r p=.08 \\
r g=.49 \\
(.17 \text { to } .84) \\
r c=- \\
r e=-.09 \\
(-.28 \text { to } .11)\end{array}$ \\
\hline Understanding & $\begin{array}{c}r p=-.29 \star \star \\
r g=-.46 \\
(-.16 \text { to }-.70) \\
r c=- \\
r e=-.24 \\
(-.05 \text { to }-.42)\end{array}$ & $\begin{array}{c}r p=.01 \\
r g=.06 \\
(-.23 \text { to } .37) \\
r c=- \\
r e=-.15 \\
(-.33 \text { to } .05)\end{array}$ & $\begin{array}{c}r p=.41^{\star \star} \\
r g=.49 \\
(.24 \text { to } .70) \\
r c=- \\
r e=.18 \\
\text { (-.02 to } .37)\end{array}$ & $\begin{array}{c}r p=.37^{\star \star} \\
r g=.65 \\
(.40 \text { to } .89) \\
r c=- \\
r e=.17 \\
(-.02 \text { to } .36)\end{array}$ & $\begin{array}{c}r p=-.18^{\star \star} \\
r g=-.08 \\
(-.34 \text { to } .18) \\
r c=- \\
r e=.02 \\
(-.18 \text { to } .23)\end{array}$ & $\begin{array}{c}r p=-.12 \\
r g=-.25 \\
(-.58 \text { to } .04) \\
r c=- \\
r e=.15 \\
(-.04 \text { to } .34)\end{array}$ & $\begin{array}{c}r p=-.30 \star \star \\
r g=-.70 \\
(-.46 \text { to }-.93) \\
r c=- \\
r e=-.09 \\
(-.28 \text { to } .11)\end{array}$ \\
\hline
\end{tabular}

Note: ${ }^{\star} p<.05,{ }^{\star \star} p<.01$ (two-tailed); values in the brackets represent the $95 \%$ confidence intervals; values in bold represent those which do not contain zero in the confidence interval.

sample size in the present study, the valence (but not the magnitude) of the genetic correlations is interpretable. Accordingly, all correlations with a $95 \%$ confidence interval that do not include zero are considered to be significantly positive or negative. Of the 63 significant phenotypic correlations, 35 were found to have significant genetic correlations ( $\mathrm{rg}$ ) suggesting that the observed correlation is partly due to common genetic effects. In addition, there were two significant common environment $(\mathrm{rc})$ correlations and six significant unique environmental (re) correlations. Seven of the pairings of values and personality were found to have significant genetic correlations, but nonsignificant phenotypic correlations. Order and self-direction was found to have a 
significant common environment correlation, but not a significant phenotypic correlation. Also, three of the pairings had significant unique environmental correlations but nonsignificant phenotypic correlations.

\section{Discussion}

As stated above, the purpose of the present study was to test whether the phenotypic correlations between values and personality can be explained by common genetic and/or environmental correlations. Two limitations in the present study were the relatively small sample size (resulting in reduced power) and the internal consistency (reliability) values for the value scales. In the present study, the scoring system described by Schwartz and Bilsky (1990), was used to generate seven value scales from the 36 items from the RVS (Rokeach, 1973). Although the internal consistency values for the generated scales were not as high as scales comprised of Likert-type response keys, the low reliability (which was probably due to the common ranking format) and sample size were not obstacles to uncovering significant systematic variance within both the univariate genetic analyses of values and the bivariate analyses of correlations between values and personality.

For instance, the univariate analyses virtually replicated those found with the PVS by Schermer et al. (2008), except for the achievement value scale. The present study found a heritable component for achievement values, but a common and unique environmental model was found to best fit the PVS achievement scale (Schermer et al., 2008). Nonetheless, Keller et al. (1992) found that achievement work values were highly heritable. In addition, even though the low reliability should attenuate correlations between values and personality, the results indicated a large number of significant correlations in theoretically consistent directions. Examples include correlations between achievement values and PRF achievement, selfdirection values and PRF autonomy, prosocial values and the PRF nurturance, security values and PRF harm avoidance, and conformity values and PRF order. On balance, then, our measures were sufficient to yield (a) genetic components similar to those found in past research and (b) correlations congruent with Schwartz's (1992) crosscultural model of values.

Thus, our principal finding is noteworthy: many of the correlations between values and conceptually related corresponding PRF scales were attributable to common genetic factors. Schermer et al. (2008) reported that many of the intercorrelations between value scales from the PVQ were from common genetic factors. The present results suggest that values may also share common genetic factors with personality. Significant unique environmental correlations were found between some of the values and PRF scales, but only the correlations between dominance and the values of achievement and restrictive conformity were found to have significant common environmental correla- tions. This finding may be explained by the fact that the PRF dominance scale is best explained by common and unique environmental influences (Vernon et al., 1997). At the same time, it remains likely that the role of conjoint environmental influences may influence the nature (e.g., frequency, extremity, vividness) of individual experiences relevant to values and personality formation.

In conclusion, the present study adds to the body of literature examining the genetic and environmental components of values and personality. We hope that this evidence stimulates future research that replicates this finding with alternative measures of values and personality. It would also be useful to see similar analyses in other cultures. Replication and extension may go a long way toward helping to understand the strong reactions that people have when values are raised and confronted within social issues, such as those outlined at the beginning of this paper. Although it is likely that we are driven to react strongly to perceived threats against values partly because of their connection to our social environment, the present evidence indicates that such reactions may also be driven by deep-seated connections to our personality and the biological fibres of our being.

\section{References}

Bouchard Jr., T. J., Segal, N. L., Tellegen, A., McGue, M., Keyes, M., \& Krueger, R. (2004). Genetic influence on social attitudes: Another challenge to psychology from behavior genetics. In L. F. Dilalla (Ed.), Behavior genetics principles: Perspectives in development, personality, and psychopathology (pp. 89-104). Washington, DC: American Psychological Association.

Furnham, A. (1984). Personality and values. Personality and Individual Differences, 5(4), 483-485.

Gibbins, K. \& Walker, I. (1993). Multiple interpretations of the Rokeach value survey. Journal of Social Psychology, 133, 797-805.

Haslam, N., Whelan, J., \& Bastian, B. (2009). Big Five traits mediate associations between values and subjective wellbeing. Personality and Individual Differences, 46, 40-42.

Jackson, D. N. (1986). Personality research form manual. Port Huron, MI: Research Psychologists Press.

Johnson, A.M., Vernon, P.A., \& Feiler, A.R. (in press). Behavioral genetic studies of personality: An introduction and review of the results of $50+$ years of research. In G. Boyle, G. Matthews \& D. Saklofske (Eds.), Handbook of personality and testing. Thousand Oaks, CA: Sage.

Keller, L. M., Bouchard, T. J. Jr., Arvey, R. D., Segal, N. L., \& Dawis, R. V. (1992). Work values: Genetic and environmental influences. Journal of Applied Psychology, 77, 79-88.

Neale, M. C., Boker S.M., Xie G., \& Maes H.H. (2006). Mx: Statistical modeling manual (7th ed.). Richmond, VA: Department of Psychiatry, Medical College of Virginia.

Neale, M. C., \& Cardon, L. R. (1992). Methodology for genetic studies of twins and families. Norwell, MA: Kluwer. 
Olver, J. M., \& Mooradian, T. A. (2003). Personality traits and personal values: A conceptual and empirical integration. Personality and Individual Differences, 35, 109-125.

Rim, Y. (1984). Importance of values according to personality, intelligence and sex. Personality and Individual Differences, 5, 245-246.

Roccas, S., Sagiv, L., Schwartz, S. H., \& Knafo, A. (2002). The Big Five personality factors and personal values. Personality and Social Psychology Bulletin, 29, 789-801.

Rokeach, M. (1973). The nature of human values. New York: Macmillan.

Schermer, J. A., Feather, N. T., Zhu, G., \& Martin, N. G. (2008). Phenotypic, genetic, and environmental properties of the portrait values questionnaire. Twin Research and Human Genetics, 11, 531-537.

Schwartz, S. H. \& Bilsky, W. (1987). Toward a universal psychological structure of human values. Journal of Personality and Social Psychology, 53, 550-562.

Schwartz, S. H. \& Bilsky, W. (1990). Toward a theory of the universal content and structure of values: Extensions and cross-cultural replications. Journal of Personality and Social Psychology, 58, 878-891.
Schwartz, S. H. Melech, G., Lehmann, A., Burgess, S., Harris, M., \& Owens, V. (2001). Extending the cross-cultural validity of the theory of basic human values with a different method of measurement. Journal of Cross-Cultural Psychology, 32, 519-542.

Schwartz, S. H., \& Rubel, T. (2005). Sex differences in value priorities: Cross-cultural and multimethod studies. Journal of Personality and Social Psychology, 89, 10101028.

Thompson, B., Levitov, J. E., \& Miederhoff, P. A. (1982). Validity of the Rokeach value survey. Educational and Psychological Measurement, 42, 899-905.

Vernon, P. A., Jang, K. L., Harris, J. A., \& McCarthy, J. M. (1997). Environmental predictors of personality differences: A twin and sibling study. Journal of Personality and Social Psychology, 72, 177-183.

Waller, N. G., Kojetin, B. A., Bouchard, T. J. Jr., Lykken, D. T., \& Tellegen, A. (1990). Genetic and environmental influences on religious interests, attitudes, and values: A study of twins reared apart and together. Psychological Science, 1, 138-142. 